NOTICE: this is the author's version of a work that was accepted for publication in Applied Geochemistry. Changes resulting from the publishing process, such as peer review, editing, corrections, structural formatting, and other quality control mechanisms may not be reflected in this document. Changes may have been made to this work since it was submitted for publication. A definitive version was subsequently published in Applied Geochemistry, Volume 21, Issue 8, August 2006, pp. 1251-1258, http://dx.doi.org/10.1016/j.apgeochem.2006.06.002 


\title{
Defects and impurities in jarosite: A computer
}

\section{simulation study}

\author{
Adrian M.L. Smith ${ }^{1,2,3,4}$, Karen A. Hudson-Edwards ${ }^{2}$, William E. Dubbin ${ }^{3}$ \\ and Kate Wright ${ }^{1,5^{*}}$
}

${ }^{1}$ Davy Faraday Research Laboratory, Royal Institution, Albermarle Street, London W1S 4BS, UK

${ }^{2}$ Research School of Earth Sciences at UCL-Birkbeck, Birkbeck, University of London, Malet Street, London, WC1E 7HX, UK

${ }^{3}$ Department of Mineralogy, The Natural History Museum, Cromwell Road, London, SW7 5BD, UK

${ }^{4}$ Now at Entec UK Ltd, Canon Court North, Abbey Lawn, Abbey Foregate, Shrewsbury, SY2 5DE, UK.

${ }^{5}$ Now at Nanochemistry Research Institute, Department of Applied Chemistry, Curtin University of Technology, GPO Box U1987, Perth, WA 6845, Australia

*Corresponding author: kate@ivec.org 


\begin{abstract}
Computer modelling techniques involving a rigid ion model have been used to investigate the defect structure and impurity site preferences in end-member Kjarosite. Calculated intrinsic vacancy energies show that the $\mathrm{K}_{2} \mathrm{SO}_{4}$ neutral cluster, with an energy per species of $1.34 \mathrm{eV}$, will be the most common defect in the pure phase. Defect reactions leading to vacancies on the Fe site have high energies, in excess of $4.0 \mathrm{eV}$ per species, and are thus unlikely to occur in great numbers. However, our calculations show that divalent metal cations can be incorporated onto the Fe site via solution reactions with oxides leading to the formation of goethite. Calculated solution reactions are exothermic and thus predicted to be highly favourable. At $\mathrm{K}$ sites substitutions occur in the order $\mathrm{Cd}>\mathrm{Zn}>\mathrm{Cu}$, but will be limited due to endothermic solution energies and structural considerations.
\end{abstract}




\section{Introduction}

Minerals of the jarosite subgroup [general formula $\mathrm{AB}_{3}\left(\mathrm{SO}_{4}\right)_{2}(\mathrm{OH})_{6}$ ] readily form in $\mathrm{Fe}(\mathrm{III})$-rich, acidic (generally $\mathrm{pH}<3$ ), oxidising acid mine / acid rock drainage (AMD / ARD) environments (Jambor, 1994; Hudson-Edwards et al., 1999). Jarosite forms indirectly from the oxidation of sulphide minerals, particularly pyrite (Rose and Cravotta, 1998). A large number of divalent cation impurities, including $\mathrm{Cd}, \mathrm{Cu}, \mathrm{Pb}$ and $\mathrm{Zn}$, can be co-precipitated with, and incorporated in, the jarosite structure (Dutrizac and Kaiman, 1976). These elements typically occupy the A or B sites where they substitute for $\mathrm{K}$ or Fe, respectively. Although considerable research has demonstrated the widespread occurrence of these elements in both natural and synthetic jarosites (e.g., Dutrizac and Dinardo, 1983; Dutrizac, 1984), no complementary theoretical modelling studies have yet been conducted to explain the potential extent and limitations of their co-precipitation within defects and vacancies in the jarosite structure. Such models provide the necessary theoretical framework in which to conduct and interpret experimental studies, especially those concerning the surface reactivity and dissolution of jarosites in aqueous systems. This paper reports the results of a computer simulation study in which we investigate structural defects and the incorporation of $\mathrm{Cd}, \mathrm{Cu}$ and $\mathrm{Zn}$ in jarosite, with two principal objectives: (i) to identify the most energetically favourable defects; and (ii) to calculate the energy for substitution of $\mathrm{Cd}(\mathrm{II}), \mathrm{Cu}(\mathrm{II})$ and $\mathrm{Zn}(\mathrm{II})$.

\section{Computational methods}

Over the last two decades, computational modelling has provided a large range of tools for exploring the structures and properties of matter at the atomic level. The range of use is now very broad, encompassing material and surface science, 
mineralogy, molecular biology and molecular chemistry (Catlow, 2003). Classical or molecular mechanics (MM) calculations use an atomistic approach, where the interactions between the atoms or ions that make up the system are described by potential functions. The lattice energy can be defined as the sum of the electrostatic or Coulombic forces acting between atoms, and the short-range repulsive forces produced by the overlap of nearest neighbour electron clouds. Short-range forces acting between non-bonded atoms in the crystal are commonly described using a Buckingham potential of the form:

$$
U\left(r_{i j}\right)=A \exp \left(-\frac{r_{i j}}{\rho}\right)-\frac{C}{r_{i j}^{6}},
$$

where the parameter A represents the repulsion between two ions $i$ and $j$ separated by a distance $r, \rho$ is related to the size and hardness of the ions and $\mathrm{C}$ is the term included to model dispersion (Gale, 1997). For bonded interactions within molecular species (e.g. $\left.(\mathrm{OH})^{-},\left(\mathrm{SO}_{4}{ }^{2-}\right)\right)$, we use the Morse potential:

$$
U\left(r_{i j}\right)=D_{i j}\left(1-\exp \left[-\alpha\left(r-r_{0}\right)\right]\right)^{2}
$$

where $\mathrm{D}$ is the bond dissociation energy, $r_{\mathrm{o}}$ is the equilibrium bond distance and $\alpha$ is a function of the slope of the potential energy well that can be obtained from spectroscopic data (Catlow and Mackrodt, 1982). Both of these potential functions are radial in nature and do not take into account directionality in bonding. When simulating systems in which covalency is important, multiple body interactions are 
commonly employed to confer directionality on the two body bonds (Catlow and Mackrodt, 1982). The three body interaction potential function is represented by:

$$
\mathrm{U}\left(\theta_{\mathrm{ijk}}\right)=\frac{1}{2} \mathrm{k}_{\mathrm{ijk}}\left(\theta_{\mathrm{ijk}}-\theta_{0}\right)^{2}
$$

where $\mathrm{k}$ is the force constant and $\theta_{i j k}$ is the bond angle acting between ions $i, j$, and $k$, and $\theta_{0}$ the equilibrium bond angle. In addition, it is possible to include the effects of oxygen ion polarisibility by the use of a shell model (Dick and Overhauser, 1956), although this feature has not been used in the current study.

Values of the variable potential parameters are derived by empirical fitting to experimental data (cell parameters, elastic and dielectric constants), or to potential energy surfaces obtained from high level ab initio calculations. Regardless of which method of fitting is used, the key quantity is the 'sum of squares' that measures the difference between calculated and experimental data. Ideally, this should be zero at the end of the fit, but in practice, this will only happen for a small number of cases (Gale, 1997). Unique fits do not exist, as there are an infinite number of possible fits depending upon the choice of the weighting factor, which in turn depends on factors such as the relative magnitude of the quantities and the reliability of the data.

In this study we have used a rigid ion model to describe the jarosite structure and its ability to host a range of impurity ions. The potential parameters for jarosite use previous literature values to describe the sulphate (Allan et al., 1993) and hydroxyl (Saul et al., 1985) molecular ions. The model has two discrete oxygen 
species: the sulphate oxygen (O1), and the hydroxyl oxygen $(\mathrm{O} 2)$ whose charges, $\mathrm{q}$, are -0.84 and -1.426 , respectively. In addition, we define a third type of oxygen, O3, with a charge $\left(q_{\text {shell }-2.86902}, q_{\text {core }} 0.86902\right)$ of -2 , used to calculate the lattice energies of oxide phases interacting with jarosite. Metal - oxygen interactions for all three oxygen types were based on literature values of Allan et al. (1993) and Woodley et al. (1999). Using these values as a starting point, a fitting procedure was carried out using the GULP code (Gale, 1997) to modify the O1-K, O1-Fe and O2-K O2-Fe parameters in order to more accurately reproduce the jarosite structure. The resulting potential parameters set is given in Table 1. Buckingham parameters for all other metal-O1 and metal-O2 interactions were derived from the metal-O3 values by scaling with respect to ionic charge (Schroder et al., 1992).

For the study of defects in jarosite, we have used the embedded cluster approach, implemented in GULP (Gale 1997) via the Mott-Littleton (ML) formalism (Mott and Littleton, 1938). In this approach, the crystal is divided into two regions: $\mathrm{R} 1$, which is spherical and contains the defect, and R2, which extends from the edge of R1 to infinity. In R1, an explicit simulation is carried out to adjust the coordinates of all ions in the region until they are at force balance; i.e. they are relaxed around the defect. The radius of $\mathrm{R} 1$ is selected so that the forces in $\mathrm{R} 2$ are relatively weak and the relaxation can be treated essentially according to the harmonic response to the defect. An interfacial region (R2A) is introduced to deal with short ranged interactions between $\mathrm{R} 1$ and the rest of $\mathrm{R} 2$, while in the outer region (R2B) the response to the net defect charge is evaluated using lattice sums. The ML method has the advantage that single charged defects or small defect clusters can be considered in isolation so as to mimic infinitely dilute concentrations. 
All crystalline solids contain an equilibrium population of point defects; i.e. vacancies and interstitials. The structure of jarosite does not contain large voids that could easily accommodate interstitial ions, and thus in this study we consider vacancies and their associated Schottky defect energies only. The energy $\left(E_{\text {Sch }}\right)$ to form a Schottky defect is defined as:

$$
E_{S c h}=E_{V 1}+E_{V 2} \ldots+E_{V n}+E_{L a t t}
$$

$E_{V 1, V 2 \ldots V n}$ are the energies required to form the individual vacancies and $E_{\text {Latt }}$ is the lattice energy of the phase removed, which is assumed to be at infinity from the defect. In the strictest sense, a Schottky defect must maintain stoichiometry as well as charge neutrality, but we also use this term to describe a number of charge neutral defect clusters.

\section{Results and discussion}

Jarosite is a member of the alunite supergroup (Jambor, 1999) consisting of isostructural minerals described by the general formula $\mathrm{AB}_{3}\left(\mathrm{TO}_{4}\right)_{2}(\mathrm{OH})_{6}$. The structure of jarosite has $R \overline{3} \mathrm{~m}$ symmetry and contains metal ions (B) located in slightly distorted octahedra. Each octahedron has four bridging hydroxyl groups in a plane, and sulphate oxygens at the apices. Three of the tetrahedral oxygens are coordinated to metal ions, and the symmetry of the $\left(\mathrm{TO}_{4}\right)^{2-}$ tetrahedra is reduced from $\mathrm{T}_{\mathrm{d}}$ to $\mathrm{C}_{3 \mathrm{v}}$. The metal ions are joined by these $\left(\mathrm{TO}_{4}\right)^{2-}$ tetrahedra and by the network of di-hydroxyl bridges to form sheets separated by the uncoordinated sulphate oxygens and the alkali A-site cations (Jambor, 1999; Becker and Gasharova, 2001). Figure 1 illustrates the above key relationships in the jarosite structure. 
We have used the GULP code (Gale, 1997) and the potential parameters listed in Table 1 to model the perfect and defective structure of end-member potassium jarosite. The calculated cell parameters and bond lengths are given in Table 2, along with the experimental values of Menchetti and Sabelli (1976) for comparison. The model gives a cell volume that is $5.17 \%$ larger than that determined by experiment, although the c/a ratio of the cell lengths is preserved. Although no data for elastic moduli are available for comparison, we note that the calculated value for bulk modulus, derived using the Ross scheme, is $68 \mathrm{GPa}$.

The intrinsic vacancy formation energies, along with the lattice energies of various strategic compounds, and the resulting Schottky defect energies, are presented in Table 3. The molecular $(\mathrm{OH})$ and $\left(\mathrm{SO}_{4}\right)$ anions are taken to be single species, as they would not dissociate without a significant energy cost. In order to compare the formation energies of different clusters, we divide the total Schottky energy by the number of species in that cluster. From Table 3, we see that the $\mathrm{K}_{2} \mathrm{SO}_{4}$ defect is predicted to be the most favourable, with an energy per species of $1.34 \mathrm{eV}$. Defect reactions giving vacancies at the $\mathrm{Fe}$ site have a much higher energy and thus we conclude that vacancies on this site will be most unfavourable. It is not possible to investigate charge neutral defect clusters of iron such as $\mathrm{Fe}(\mathrm{OH})_{3}$ or $\mathrm{Fe}_{2}\left(\mathrm{SO}_{4}\right)_{3}$, as these compounds are unstable in their non-hydrated forms and their lattice energy cannot be calculated. For defect reactions involving the formation of goethite $[\alpha-$ $\mathrm{FeO}(\mathrm{OH})]$, a product of jarosite breakdown (Smith et al., in press), the defect cluster $\left[\mathrm{V}_{\mathrm{Fe}}+3 \mathrm{~V}_{\mathrm{OH}}\right]^{\mathrm{x}}$ must undergo a proton transfer reaction to give $\mathrm{FeO}(\mathrm{OH})+\mathrm{H}_{2} \mathrm{O}$. An approximate value for this reaction can be obtained by using a value for the proton transfer energy of $9.74 \mathrm{eV}$ (Wright et al., 1994) and an energy of $-6.43 \mathrm{eV}$ (de Leeuw 
and Parker, 1998) for the self energy of the water molecule. Summing all the energy terms:

$$
E_{V F e}+3 E_{V O H}+E_{P T}+E_{\text {FеOOH }}+E_{H 2 O}
$$

gives $42.33 \mathrm{eV}$ (10.5 eV per defect species), suggesting once again that vacancies on the Fe site will not be energetically favourable.

Minerals are rarely found in nature as pure compounds and may contain a wide variety of impurity species that substitute for other ions in the structure. Some minerals only allow small deviations from their pure endmember compositions, while in others there is a continuous solid solution between two extreme compositions. It is well known that jarosite can host a whole range of impurities, although in this study we confine our calculations to the study of three $2+$ cations commonly observed in the structure and seen in ARD environments: $\mathrm{Cd}(\mathrm{II}), \mathrm{Zn}(\mathrm{II})$, and $\mathrm{Cu}(\mathrm{II})$ (Dutrizac, 1984; Alpers et al., 1992; Dutrizac et al., 1996). Each of the three impurity ions was placed at the $\mathrm{K}$ site and the Fe site to obtain the substitution energy. In all cases, other defects had to be introduced in order to maintain charge neutrality, so that we have three sets of possible defect pairs for each metal impurity: $M_{K}^{\cdot}+V_{K}^{\prime}, M_{K}^{\cdot}+M_{F e}^{\prime}$, and $M_{F e}^{\prime}+V_{O H}^{\cdot}$, where $M_{K}^{\cdot}$ represents an impurity at the $\mathrm{K}$ site and is positively charged, $V_{K}^{\prime}$ is a negatively charged $\mathrm{K}$ vacancy, $M_{F e}^{\prime}$, a negatively charged substitution and $V_{O H}^{\cdot}$ a positively charged vacancy. The formation energies of the neutral defect pairs are given (Table 4) for the case where the impurities are assumed to be at infinite distance from each other and therefore not interacting (unbound), and for the bound case where they are adjacent to each other. In all cases, the binding energy is negative so that there is a definite energy gain, and hence a driving force, to bind together. The most stable defect pair is $M_{K}^{\cdot}+V_{K}^{\prime}$, where substitutions are favoured in the order $\mathrm{Cu}>\mathrm{Zn}>$ $\mathrm{Cd}$ and binding energies are small. This agrees with experimental work on synthetic 
jarosites (Jambor and Dutrizac, 1985; Dutrizac et al., 1996). For the $M_{F e}^{\prime}+V_{O H}^{\cdot}$ defect pair, the order changes when bound defect pairs are considered, as there is a large binding energy for the $\mathrm{Zn}$ and $\mathrm{V}_{\mathrm{OH}}$ in this configuration. For the third type of defect pair, $M_{K}^{\cdot}+M_{F e}^{\prime}$, the possibility also exists for mixed metal substitutions, as shown in Table 5. Once again, all binding energies are negative, so that there is a strong possibility of impurities clustering together, presumably due to the more uniform charge distribution.

These results show only the difference between the lattice with the substitution and without, but give no indication if the substitution will occur. In order to assess the probability of substitution, the full solution reaction of jarosite with some compound containing the impurity must be considered. In nature, such reactions are likely to be complicated, as impurities may be in solution, or in complex hydrated phases, and reaction energies will ultimately depend on the chosen products and reactants. In order to gain insights into general trends, we look at solution reactions of jarosite with sulphate and oxide phases leading to the defect complexes in Tables 4 and 5.

In the case of oxides, solution reactions leading to substitution on both the $\mathrm{K}$ and $\mathrm{Fe}$ site are possible.

$$
\begin{aligned}
& \mathrm{MO}+2 \mathrm{~K}_{\mathrm{K}}^{\mathrm{x}} \Rightarrow \mathrm{M}_{\mathrm{K}}^{\cdot}+\mathrm{V}_{\mathrm{K}}^{\prime}+\mathrm{K}_{2} \mathrm{O} \\
& \mathrm{MO}+\mathrm{Fe}_{\mathrm{Fe}}^{\mathrm{x}}+\mathrm{OH}_{\mathrm{O}}^{\mathrm{x}} \Rightarrow \mathrm{M}_{\mathrm{Fe}}^{\prime}+\mathrm{V}_{\mathrm{OH}}^{\cdot}+\mathrm{FeOOH}
\end{aligned}
$$

In Equation (6), a cation substitutes at a $\mathrm{K}$ site, is charge balanced by a $\mathrm{K}$ vacancy, and one unit of $\mathrm{K}_{2} \mathrm{O}$ is formed. Similarly, the substitution of the $2+$ cation at the $\mathrm{Fe}$ site in Equation (7) is charge balanced by a $(\mathrm{OH})$ vacancy and forms one unit of $\mathrm{FeOOH}$. Reactions with sulphates can be written in a similar manner although the Fe substitution in Equation (9) is charge balanced by a coupled substitution at the K site.

$$
\mathrm{MSO}_{4}+2 \mathrm{~K}_{\mathrm{K}}^{\mathrm{x}} \Rightarrow \mathrm{M}_{\mathrm{K}}^{\cdot}+\mathrm{V}_{\mathrm{K}}^{\prime}+\mathrm{K}_{2} \mathrm{SO}_{4}
$$




$$
2 \mathrm{MSO}_{4}+\mathrm{K}_{\mathrm{K}}^{\mathrm{x}}+\mathrm{Fe}_{\mathrm{Fe}}^{\mathrm{x}} \Rightarrow \mathrm{M}_{\mathrm{K}}^{\cdot}+\mathrm{M}_{\mathrm{Fe}}^{\prime}+\mathrm{KFe}\left(\mathrm{SO}_{4}\right)_{2}
$$

The solution energy $\left(\mathrm{E}_{\mathrm{sol}}\right)$ is obtained from the sum of the terms in each equation. We calculate $\mathrm{E}_{\mathrm{sol}}$ for reactions with $\mathrm{ZnSO}_{4}, \mathrm{CuSO}_{4}$, and $\mathrm{CdSO}_{4}$, and with $\mathrm{ZnO}$ and $\mathrm{CdO}$. $\mathrm{CuO}$ was not included as our potentials are unable to model the properties of this phase adequately. Solution reaction energies are presented in Table 7, using calculated values of lattice energies from Tables 1 and 6 .

Looking at the results presented in Tables 4-7, some very general trends can be identified. Firstly, reactions with $\mathrm{Zn}$ - and Cd- oxide phases, where the impurity ion substitutes for Fe leading to the formation of goethite (Equation 7), are predicted to be exothermic and thus highly favourable. Although we are not able to obtain the solution energy for $\mathrm{CuO}$, it is likely that it too would be exothermic, as the substitution energy (Table 4) is mid way between that of $\mathrm{Zn}$ and $\mathrm{Cd}$. For $\mathrm{K}$ site substitutions, incorporation via reactions with sulphates (Equation 8) have the lowest energy, where the order of incorporation is $\mathrm{Cd}>\mathrm{Zn}>\mathrm{Cu}$. The $\mathrm{K}$ site reaction described by Equation 6 and the coupled substitution reactions (Equation 9) however, are not favourable routes for the uptake of impurities.

Attempts at optimising a structure with half of the $\mathrm{K}$ sites occupied by $\mathrm{Cd}$ and the other half vacant failed as the structure became unstable, presumably due to the differences in ionic radii. The same failure resulted when $\mathrm{Cd}$ was replaced by $\mathrm{Cu}$ and by $\mathrm{Zn}$. Certainly no natural or synthetic end member $\mathrm{Cd}, \mathrm{Cu}$ or $\mathrm{Zn}$ jarosites are known. In natural and synthetic jarosites, $\mathrm{Pb}$ occurs with $\mathrm{Cu}$ and $\mathrm{Zn}$, such that there is complete solid solution between plumbojarosite $\left[\mathrm{Pb}_{0.5} \mathrm{Fe}_{3}\left(\mathrm{SO}_{4}\right)_{2}(\mathrm{OH})_{6}\right]$ and beaverite$\mathrm{Cu}\left[\mathrm{Pb}(\mathrm{Cu}, \mathrm{Fe})_{3}\left(\mathrm{SO}_{4}\right)_{2}(\mathrm{OH})_{6}\right]$ or beaverite- $\mathrm{Zn}\left[\mathrm{Pb}(\mathrm{Zn}, \mathrm{Fe})_{3}\left(\mathrm{SO}_{4}\right)_{2}(\mathrm{OH})_{6}\right]$ (Jambor and Dutrizac, 1983, 1985). The $\mathrm{Pb}$ ion has a much larger ionic radius and can therefore prevent collapse of the lattice. Unfortunately we have been unable to model $\mathrm{Pb}$ 
impurities, as the lone electron pair on the $\mathrm{Pb}^{2+}$ ion is not well described by interatomic potential methods. Because of its large ionic radius, $\mathrm{Pb}$ will always prefer the $\mathrm{K}$ site, and thus any subsequent metal impurities will be forced into the Fe site in order to reduce overall lattice energy. The inference that $2+$ impurity cations are theoretically more energetically favourable when occupying the octahedral 3+ B-site supports data from experimental (Dutrizac, 1984; Dutrizac et al., 1996) and natural settings affected by AMD/ARD (McGregor et al., 1998). Studies of natural and synthetic samples suggest that the substitutions are limited in non-beaverite jarosites. For example, in $\mathrm{Pb}$ and other jarosites, only $1-2 \mathrm{wt} \% \mathrm{Zn}$ can be incorporated, and only up to 5 wt.\% Zn in lead jarosite (Dutrizac and Dinardo, 1983; Jambor and Dutrizac, 1983, 1985). Dutrizac (1984) found that end-member Na jarosite could incorporate only 2 wt. $\% \mathrm{Cu}$.

\section{Conclusions}

The potential parameter set used in this study is able to provide a good description of the bulk jarosite structure, and to give information on site preferences for impurity incorporation at the $\mathrm{K}$ and $\mathrm{Fe}$ sites. Our calculations show that the $\mathrm{K}_{2} \mathrm{SO}_{4}$ Schottky is the most energetically favourable intrinsic defect. The two other Schottky defects considered both contain Fe vacancies and have similar, higher, energies per defect species. This leads us to conclude that removal of Fe from the lattice is unlikely to occur in any appreciable amount as it destabilises the structure. Measured Fe deficiency is likely to be coupled with substitutions on the vacant site to minimise such disruption. 
Using our model, we have also calculated the energy for solution of $\mathrm{Cd}(\mathrm{II})$, $\mathrm{Cu}(\mathrm{II})$ and $\mathrm{Zn}$ (II) at both $\mathrm{K}$ and $\mathrm{Fe}$ sites in jarosite via reactions with oxides and sulphates. These impurities are most easily incorporated into the lattice at Fe sites, with corresponding $\mathrm{OH}$ vacancies providing charge neutrality, and leading to the formation of $\mathrm{FeOOH}$. Calculated solution energies for $\mathrm{Zn}$ and $\mathrm{Cd}$ incorporation via this mechanism are exothermic. The order of substitution is predicted to be $\mathrm{Cd}>\mathrm{Zn}>\mathrm{Cu}$ for $\mathrm{K}$ sites and $\mathrm{Zn}>\mathrm{Cu}>\mathrm{Cd}$ for Fe sites. Differences in ionic radii are likely to inhibit the formation of $\mathrm{Zn}-\mathrm{Cu}$ - and $\mathrm{Cd}$ - end member jarosites, as this destabilises the structure. Our study illustrates the value of computational modelling in predicting the incorporation of impurities into jarosite, and highlights its potential for similar studies on other common AMD/ARD minerals.

\section{Acknowledgements}

This work was funded through a UK Engineering and Physical Sciences Research Council (EPSRC) studentship award (number 309778) to A.M.L. Smith. We also wish to thank the EPSRC for provision of computational resources. In addition, we thank the two anonymous reviewers for their insightful comments that improved the manuscript. 


\section{References}

Allan, N.L., Rohl, A.L., Gay, D.H., Catlow, C.R.A., Davey, R.J., Mackrodt, W.C., 1993. Calculated bulk and surface properties of sulfates. Faraday Disc. 95, 273280.

Alpers, C.N., Rye, R.O., Nordstrom, D.K., White, L.D., Bi-Shia, King, 1992. Chemical, crystallographic and stable isotopic properties of alunite and jarosite from acid-hypersaline Australian lakes. Chem. Geol. 96, 203-226.

Becker, U., Gasharova, B., 2001. AFM observations and simulations of jarosite growth at the molecular scale: probing the basis for the incorporation of foreign ions into jarosite as a storage mineral. Phys. Chem. Mineral. 28, 545-556.

Catlow, C.R.A., 2003. Computer modelling of materials: an introduction. In: Catlow, C.R.A., Kotomin, E. (Eds.), Computational Materials Science. NATO Science Series, IOS Press.

Catlow, C.R.A., Mackrodt, W.C., 1982. Computer simulation of solids. Lecture Notes in Physics, vol. 166.

Dick B.G., Overhauser A.W., 1956. Theory of the dielectric constants of alkali halide crystals. Phys Rev 112:90-103

de Leeuw, N.H., Parker S.C., 1998. Molecular-dynamics simulation of MgO surfaces in liquid water using a shell-model potential for water. Physical Review B 58, 13901-13908.

Dutrizac, J.E., 1984. The behaviour of impurities during jarosite precipitation. In Bautista, R.G. (Ed.), Hydrometallurgical Process Fundamentals. Plenum Press, New York, 125-169. 
Dutrizac, J.E., Dinardo, O., 1983. An overview of iron precipitation technologies and the incorporation of divalent ions in jarosite-type compounds. J. Metals 35, 96-97.

Dutrizac, J.E., Kaiman, S., 1976. Synthesis and properties of jarosite-type compounds. Can. Mineral. 14, 151-158.

Dutrizac, J.E., Hardy, D.J., Chen, T.T., 1996. The behaviour of cadmium during jarosite precipitation. Hydrometallurgy 41, 269-285.

Gale, J.D., 1997. GULP: A computer program for the symmetry-adapted simulation of solids. J. Chem. Soc. - Faraday Trans. 93, 629-637.

Hudson-Edwards, K.A., Schell, C., Macklin, M.G., 1999. Mineralogy and geochemistry of alluvium contaminated by metal mining in the Rio Tinto area, southwest Spain. Appl. Geochem. 14, 55-70.

Jambor, J.L., 1994. Mineralogy of sulfide-rich tailings and their oxidation products. In Jambor, J.L., Blowes, D.W. (Eds.) The Environmental Geochemistry of Sulfide Mine-Wastes. Mineral. Assoc. Canada Short Course 22, 59-102.

Jambor, J.L., 1999. Nomenclature of the alunite supergroup. Can. Mineral. 37, 13231341.

Jambor, J.L., Dutrizac, J.E., 1983. Beaverite-plumbojarosite solid solutions. Can. Mineral. 21, 101-113.

Jambor, J.L., Dutrizac, J.E., 1985. The synthesis of beaverite. Can. Mineral. 23, 4751.

McGregor, R.C., Blowes, D.W., Jambor, J.L., Robertson, W.D., 1998. The solidphase controls on the mobility of heavy metals at the Copper Cliff tailings area, Sudbury, Ontario, Canada. J. Contaminant Hydrol. 33, 247-271. 
Menchetti, S., Sabelli, C., 1976. Crystal chemistry of the alunite series; crystal structure refinement of alunite and synthetic jarosite. Neues Jahrbuch fuer Mineralogie, Monatshefte 9, 406-417.

Mott, N.F., Littleton, M.J., 1938. Conduction in polar crystals. I. Electrolytic conduction in solid salts. Trans. Farad. Soc. 34, 485-491.

Rose, A.W., Cravotta, C.A.III, 1998. Geochemistry of coal mine drainage. In Brady, K.B.C., Smith, M.W., Schueck, J. (Eds.), Coal Mine Drainage Prediction and Prevention in Pennsylvania. Pennsylvannia Dept. Environ. Protection, Harrisburg, PA.

Saul, P., Catlow, C.R.A., Kendrick, J., 1985. Theoretical-studies of protons in sodium-hydroxide. Phil. Mag. B - Phys. Condensed Matter Statistical Mechanics Electronic Optical and Magnetic Properties 51, 107-117.

Schroder, K.P., Sauer, J., Leslie, M., Catlow, C.R.A., Thomas, J.M., 1992. Bridging hydroxyl-groups in zeolotic catalysts - a computer-simulation of their structure, vibrational properties and acidity in protonated faujasites (H-Y zeolites). Chem. Phys. Lett. 188, 320-325.

Smith, A.M.L., Hudson-Edwards, K.A., Dubbin, W.E., Wright, K., (in press). Dissolution of jarosite $\left[\mathrm{KFe}_{3}\left(\mathrm{SO}_{4}\right)_{2}(\mathrm{OH})_{6}\right]$ at $\mathrm{pH} 2$ and 8: Insights from batch experiments and computational modelling. Geochim. Cosmochim. Acta.

Woodley, S.M., Battle, P.D., Gale, J.D., Catlow, C.R.A., 1999. The prediction of inorganic crystal structures using a genetic algorithm and energy minimisation. Phys. Chem. Chem. Phys. 1, 2535-2542.

Wright K., Freer R., Catlow C.R.A., 1994. The energetics and structure of the hydrogarnet defect in grossular: a computer simulation study. Phys Chem. Minerals 20, 500-503. 
FIGURES and TABLES

Figure 1. Structure of end-member K jarosite.

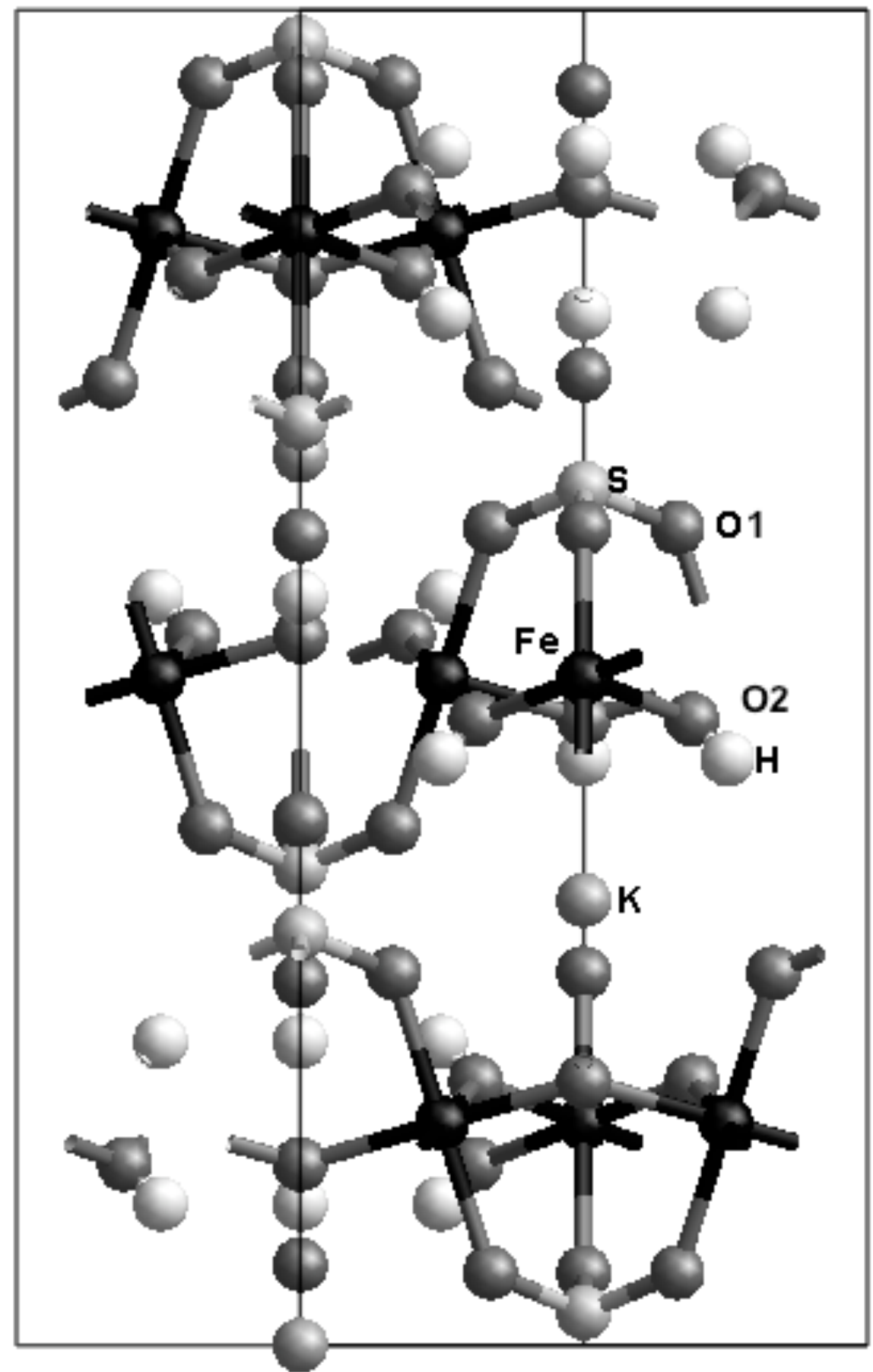


Table 1. Potential parameters used to model end-member potassium jarosite. O1 represents the sulphate oxygen $(q=-0.84)$ and $\mathrm{O} 2$ the hydroxyl oxygen $(q=-1.426)$. O3 is described by a shell model ( $q$ shell $=-2.86902$, qcore $=0.86902$ ) whose spring constant $\left(\mathrm{k}_{\mathrm{s}}\right)$ has a value of 74.92038 and is used to calculate the lattice energies of the oxide phases in Table 6. The short range Buckingham potential cutoff was set to $10 \AA$.

\begin{tabular}{lllll}
\hline Buckingham & $\mathrm{A} / \mathrm{eV}$ & $\rho / \AA$ & $\mathrm{C} / \mathrm{eV} \AA^{6}$ & $\mathrm{Ref}$. \\
\hline $\mathrm{K}-\mathrm{O} 1$ & 987.570 & 0.300 & 0.00 & $\mathrm{a}$ \\
$\mathrm{K}-\mathrm{O} 2$ & 1587.570 & 0.300 & 0.00 & $\mathrm{a}$ \\
$\mathrm{K}-\mathrm{O} 3$ & 3587.57 & 0.300 & 0.00 & $\mathrm{~b}$ \\
$\mathrm{Fe}-\mathrm{O} 1$ & 3219.335 & 0.2641 & 0.00 & $\mathrm{~b}$ \\
$\mathrm{Fe}-\mathrm{O} 2$ & 3219.335 & 0.2641 & 0.00 & $\mathrm{~b}$ \\
$\mathrm{Fe}-\mathrm{O} 3$ & 3219.335 & 0.2641 & 0.00 & $\mathrm{~b}$ \\
$\mathrm{O} 1-\mathrm{O} 1$ & 103585.02 & 0.2 & 25.98 & $\mathrm{a}$ \\
$\mathrm{O} 2-\mathrm{O} 2$ & 103585.02 & 0.2 & 25.98 & $\mathrm{a}$ \\
$\mathrm{O} 1-\mathrm{O} 2$ & 103585.02 & 0.2 & 25.98 & $\mathrm{a}$ \\
$\mathrm{O} 3-\mathrm{O} 3$ & 22764.0 & 0.149 & 27.88 & $\mathrm{~b}$ \\
$\mathrm{Cd}-\mathrm{O} 1$ & 364.868 & 0.35 & 0.0 & $\mathrm{~b}$ \\
$\mathrm{Cd}-\mathrm{O} 2$ & 619.0979 & 0.35 & 0.0 & $\mathrm{~b}$ \\
$\mathrm{Cd}-\mathrm{O} 3$ & 868.30 & 0.35 & 0.0 & $\mathrm{~b}$ \\
$\mathrm{Zn}-\mathrm{O} 1$ & 294.126 & 0.3372 & 0.0 & $\mathrm{~b}$ \\
$\mathrm{Zn}-\mathrm{O} 2$ & 499.313 & 0.3372 & 0.0 & $\mathrm{~b}$ \\
$\mathrm{Zn}-\mathrm{O} 3$ & 499.60 & 0.3595 & 0.0 & $\mathrm{~b}$ \\
$\mathrm{Cu}-\mathrm{O} 1$ & 700.1988 & 0.3 & 0.0 & $\mathrm{~b}$ \\
$\mathrm{Cu}-\mathrm{O} 2$ & 1188.67 & 0.3 & 0.0 & $\mathrm{~b}$ \\
$\mathrm{Morse}$ & $\mathrm{D} / \mathrm{eV}$ & $\alpha / \AA^{-1}$ & $\mathrm{r}_{\mathrm{o}} / \AA$ & \\
$\mathrm{S}-\mathrm{O} 1$ & 5.0 & 1.2 & 1.465 & $\mathrm{c}$ \\
$\mathrm{H}-\mathrm{O} 2$ & 7.0525 & 1.9 & 0.9685 & $\mathrm{~d}$ \\
$\mathrm{Three}-\mathrm{b} 0 d y$ & $\mathrm{k}_{3} / \mathrm{eV} \mathrm{rad}^{-2}$ & $\theta /{ }^{\circ}$ & & \\
$\mathrm{O} 1-\mathrm{S}-\mathrm{O} 1$ & 15.00 & 109.47 & & $\mathrm{c}$ \\
\hline
\end{tabular}

Refs. ${ }^{\mathrm{a}}$ fitted, this study, ${ }^{\mathrm{b}}$ Woodley et al. (1999), ${ }^{\mathrm{c}}$ Allan et al. (1993), ${ }^{\mathrm{d}}$ Saul et al. (1985) 
Table 2. Comparison of experimental (Menchetti and Sabelli, 1976) and calculated cell parameters and interatomic distances and angles for jarosite. All distances in angstroms $(\AA)$.

\begin{tabular}{|c|c|c|}
\hline & Expt. & Calc. (\% difference) \\
\hline $\mathrm{a}$ & 7.315 & $7.443(1.75)$ \\
\hline $\mathrm{b}$ & 7.315 & $7.443(1.75)$ \\
\hline $\mathrm{c}$ & 17.224 & $17.497(1.58)$ \\
\hline $\operatorname{Vol}\left(\AA^{3}\right)$ & 798.17 & $839.40(5.17)$ \\
\hline $\mathrm{a} / \mathrm{c}$ & 0.4247 & $0.4254(0.16)$ \\
\hline \multicolumn{3}{|l|}{ Bond lengths } \\
\hline $\mathrm{S}-\mathrm{O}$ & 1.465 & 1.466 \\
\hline $\mathrm{S}-\mathrm{O} \times 3$ & 1.481 & 1.543 \\
\hline $\mathrm{K}-\mathrm{O} \times 6$ & 2.828 & 2.941 \\
\hline $\mathrm{K}-\mathrm{O} \times 6$ & 2.978 & 2.981 \\
\hline $\mathrm{Fe}-\mathrm{O} \times 2$ & 2.058 & 2.192 \\
\hline $\mathrm{Fe}-\mathrm{O} \times 4$ & 1.975 & 1.988 \\
\hline $\mathrm{O}-\mathrm{H}$ & 0.750 & 0.882 \\
\hline $\mathrm{O}-\mathrm{H} \ldots \mathrm{O}$ & 2.220 & 2.096 \\
\hline $\mathrm{O}-\mathrm{H} \ldots \mathrm{O}$ & 2.942 & 2.939 \\
\hline \multicolumn{3}{|l|}{ Bond angles } \\
\hline $\mathrm{O}-\mathrm{Fe}-\mathrm{O}$ & $91.2^{\circ}$ & $90.19^{\circ}$ \\
\hline $\mathrm{O}-\mathrm{Fe}-\mathrm{O}$ & $88.8^{\circ}$ & $89.81^{\circ}$ \\
\hline $\mathrm{O}-\mathrm{Fe}-\mathrm{O}$ & $88.8^{\circ}$ & $88.92^{\circ}$ \\
\hline $\mathrm{O}-\mathrm{Fe}-\mathrm{O}$ & $91.2^{\circ}$ & $91.08^{\circ}$ \\
\hline $\mathrm{Fe}-\mathrm{O}-\mathrm{Fe}$ & $135^{\circ}$ & $138.73^{\circ}$ \\
\hline
\end{tabular}


Table 3. Calculated vacancy and Schottky defect formation energies, plus relevant lattice energies.

Values in parentheses represent the energy per defect species.

\begin{tabular}{cc}
\hline Defect & Energy $(\mathrm{eV})$ \\
\hline $\mathrm{V}_{\mathrm{K}}^{\prime}$ & 4.76 \\
$\mathrm{~V}_{\mathrm{Fe}}^{\prime \prime \prime}$ & 49.29 \\
$\mathrm{~V}_{\mathrm{SO} 4} \cdot$ & 50.64 \\
$\mathrm{~V}_{\mathrm{OH}}{ }^{\prime}$ & 26.81 \\
Lattice & -55.82 \\
$\mathrm{~K}_{2} \mathrm{SO}_{4}$ & -137.06 \\
$\mathrm{KFe}\left(\mathrm{SO}_{4}\right)_{2}$ & -357.37 \\
$\mathrm{KFe}_{3}\left(\mathrm{SO}_{4}\right)_{2}(\mathrm{OH})_{6}$ & \\
$\mathrm{Schottky}$ & $4.02(1.34)$ \\
$\mathrm{K}_{2} \mathrm{SO}_{4}$ & $17.11(4.27)$ \\
$\mathrm{KFe}_{\left(\mathrm{SO}_{4}\right)_{2}}$ & $54.26(4.52)$ \\
$\mathrm{KFe}_{3}\left(\mathrm{SO}_{4}\right)_{2}(\mathrm{OH})_{6}$ & \\
\hline
\end{tabular}

Table 4. Calculated bound (B) and unbound (UB) impurity substitution energies (eV) charge balanced by a vacancy. Numbers in parentheses are the binding energies $(\mathrm{eV})$.

\begin{tabular}{lllll}
\hline & & $M_{K}^{\cdot}+V_{K}^{\prime}$ & & $M_{F e}^{\prime}+V_{O H}^{\cdot}$ \\
\hline & $\mathrm{UB}$ & $\mathrm{B}\left(\mathrm{E}_{\mathrm{B}}\right)$ & $\mathrm{UB}$ & $\mathrm{B}\left(\mathrm{E}_{\mathrm{B}}\right)$ \\
$\mathrm{Cd}$ & -6.28 & $-6.95(-0.67)$ & 53.07 & $52.52(-0.55)$ \\
$\mathrm{Cu}$ & -7.17 & $-7.77(-0.60)$ & 50.93 & $50.38(-0.55)$ \\
$\mathrm{Zn}$ & -6.63 & $-7.27(-0.64)$ & 52.13 & $49.28(-2.85)$ \\
\hline
\end{tabular}

Table 5. Calculated bound and unbound couple substitution energies (eV)

\begin{tabular}{llll}
\hline K site & $\mathrm{Fe}$ site & $\mathrm{UB}$ & $\mathrm{B}\left(\mathrm{E}_{\mathrm{B}}\right)$ \\
\hline $\mathrm{Cu}$ & $\mathrm{Cu}$ & 12.26 & $10.98(-1.28)$ \\
$\mathrm{Cd}$ & $\mathrm{Cu}$ & 13.15 & $11.49(-1.66)$ \\
$\mathrm{Zn}$ & $\mathrm{Cu}$ & 12.97 & $11.60(-1.37)$ \\
$\mathrm{Cu}$ & $\mathrm{Zn}$ & 13.46 & $12.14(-1.32)$ \\
$\mathrm{Cd}$ & $\mathrm{Zn}$ & 14.35 & $12.61(-1.74)$ \\
$\mathrm{Zn}$ & $\mathrm{Zn}$ & 14.00 & $12.84(-1.16)$ \\
$\mathrm{Cu}$ & $\mathrm{Cd}$ & 14.40 & $13.11(-1.29)$ \\
$\mathrm{Zn}$ & $\mathrm{Cd}$ & 14.94 & $13.78(-1.16)$ \\
$\mathrm{Cd}$ & $\mathrm{Cd}$ & 15.29 & $14.24(-1.05)$ \\
\hline
\end{tabular}


Table 6. Calculated lattice energies of reactant phases used to determine solution energies.

\begin{tabular}{lc}
\hline Phase & Lattice energy $(\mathrm{eV})$ \\
\hline $\mathrm{CdO}$ & -36.59 \\
$\mathrm{ZnO}$ & -39.66 \\
$\mathrm{CdSO}_{4}$ & -64.65 \\
$\mathrm{CuSO}_{4}$ & -66.07 \\
$\mathrm{ZnSO}_{4}$ & -65.29 \\
$\mathrm{FeOOH}$ & -90.70 \\
\hline
\end{tabular}

Table 7. Solution energies (Equations 6-9) for the incorporation of impurities into jarosite, calculated using bound substitution energies (Tables 4 and 5) and the lattice energies given in Table 6.

\begin{tabular}{lccc}
\hline Reactant & & $\mathrm{E}_{\text {Solo }}(\mathrm{eV})$ & $\mathrm{E}_{\mathrm{Sol}}(\mathrm{eV})$ \\
\hline Oxide & Eq. 6 & Eq. 7 \\
$\mathrm{CdO}$ & 6.23 & -1.59 \\
$\mathrm{ZnO}$ & 8.97 & -1.76 \\
& & & \\
Sulphate & & 1.88 & 6.48 \\
$\mathrm{CdSO}_{4}$ & & 2.48 & 6.06 \\
$\mathrm{CuSO}_{4}$ & & 2.19 & 6.07 \\
$\mathrm{ZnSO}_{4}$ & & 5.15 \\
$\mathrm{CdSO}_{4}+\mathrm{CuSO}_{4}$ & $\left(\mathrm{Cd}_{\mathrm{K}}+\mathrm{Cu}_{\mathrm{Fe}}\right)$ & & 6.77 \\
$\mathrm{CdSO}_{4}+\mathrm{CuSO}_{4}$ & $\left(\mathrm{Cu}_{\mathrm{K}}+\mathrm{Cd}_{\mathrm{Fe}}\right)$ & & 5.49 \\
$\mathrm{CdSO}_{4}+\mathrm{ZnSO}_{4}$ & $\left(\mathrm{Cd}_{\mathrm{K}}+\mathrm{Zn}_{\mathrm{Fe}}\right)$ & & 6.66 \\
$\mathrm{CdSO}_{4}+\mathrm{ZnSO}_{4}$ & $\left(\mathrm{Zn}_{\mathrm{K}}+\mathrm{Cd}_{\mathrm{Fe}}\right)$ & & 6.44 \\
$\mathrm{CuSO}_{4}+\mathrm{ZnSO}_{4}$ & $\left(\mathrm{Cu}_{\mathrm{K}}+\mathrm{Zn}_{\mathrm{Fe}}\right)$ & & 5.90 \\
$\mathrm{CuSO}_{4}+\mathrm{ZnSO}_{4}\left(\mathrm{Zn}_{\mathrm{K}}+\mathrm{Cu}_{\mathrm{Fe}}\right)$ & & \\
\hline
\end{tabular}

